\title{
Socio-Economic Determinants of Rural Migrants in Urban Setting: A Study Conducted at City Sargodha, Pakistan
}

\author{
Faisal Imran \\ Department of Sociology, \\ University of Sargodha, Pakistan \\ Yasir Nawaz \\ Assistant Professor, Department of Sociology,
University of Sargodha Pakistan E. mail: vasit:manj@uos.edu.pk \\ Muhammad Asim \\ M. Phil Scholar Department of Sociology \\ G.C.University Faisalabad, Pakistan E.mail:masim202@gmail.com

\section{Arshad H. Hashmi} \\ University of Veterinary and Animal Sciences, Lahore, Pakistan
}

Doi:10.5901/ajis/2013.v2n1p71

\section{Abstract}

Migration is universal phenomena and people move from rural areas to urban areas, from developing countries to developed countries and from societies with stagnant economic conditions to societies with better off economic conditions to address their economic and social needs. The present study was designed to explore the socio-economic determinants of rural migrants in urban settings in Sargodha city. For the purpose of the study existing literature on the topics was thoroughly reviewed. A sample of I20 respondents was taken equally ( 40 from each colony) three randomly selected localities i.e. Satellite Town, Farooq Colony and Old Civil Line. Descriptive analysis demonstrates that insufficient, inappropriate educational, health, recreational facilities, poor infrastructure and stagnant and limited economic opportunities in rural areas were the prime factors which motivate the individuals and families to migrate to the urban areas. With increasing migration from rural to urban areas, the multi-dimensional problems such sanitation, environmental pollution, overcrowded housing, congested traffic, overpopulation, road accidents and crimes are increasing. Government should have provide better economic opportunities, better sanitation facilities, better health facilities better educational facilities, better infrastructure, better transportation, promotion of cottage industry, and establishment of small industry near the villages to divert the major flow of people from rural areas to urban areas.

Key words: Migration, Socio- economic determinants, Push and pull factors and Rural and Urban areas

\section{Introduction}

Migration is defined as "the crossing of the boundary of a pre defined spatial unit by persons involved in a change of residence" (Henderson, 2002). Economic development leads to structural transformation and as a result, the share of agriculture sector declines while that of industrial sector increases in the 
country's Gross Domestic Product (GDP). As the industrial output increases, employment opportunities at the urban centers also increases and people begin moving from the rural subsistence agriculture sector to the urban areas in search of better employment opportunities and better living conditions (Sadaf et al, 2010). This phenomenon increase in the urban population as a consequence of the mass movement of people to urban centers is commonly referred to as urbanization. However, movement of people from the rural subsistence agricultural sector is not the only cause of urbanization, the higher population growth rate especially in the developing world is also a major reason of the growing trend of urbanization. The process of urbanization on the one hand, provides opportunities of better standard of living, while it is also having certain negative effects such as congestion, environmental pollution, and an increase in crimes and so on. Urbanization is of many developing countries and Pakistan is no exception. During the last 63 years, the total population of Pakistan in general and of Pakistani cities in particular increased manifolds (Izhar et al, 20I0). The overall population increased by more than 52.5\% during I95I and 20I0. In I95I, 82.26\% of the total Population lived in rural areas whereas this figure dropped down to only $66 \%$ in 2008. The current estimated Population growth rate of Pakistan is $1.513 \%$ while the population growth rate of cities is $3 \%$ which clearly points out that rural-urban migration is nearly $2 \%$ annually (Anonymous, 20II).

Pakistan is country with I80 million and population growth is also high as compared to many developing countries. More than 68 percent population lives in rural areas in extreme poor socioeconomic conditions. As different studies indicate that more than one third of rural population is below the poverty line along with further division of land into the growing families. People find no way other than migration to urban areas to address their socio-economic and health needs. In Pakistan migration has always been an important phenomenon. After independence in 1947, a population exchange between India and Pakistan took on a scale never before recorded in human history, involving more than I4 million people (Arif and Hamid, 2009). People tend to move from one area whether rural or urban, developing country or developed country keeping in view multi-dimensional aspects, motives or causes. The decision to move is based on certain felt deprivations, stress, constraints, aspirations, motivation at the place of origin. Deprivations are felt by collectively or individuals when the immediate needs are not fulfilled by the existing conditions within a community (Haq, 1974). There are many economic, social and political and environmental factors which caused by migration, and they can usually be classified into push and pull factors. Push factors are those associated with the area of origin, while pull factors are those that are associated with the area of destination (Riley, 20II).

\section{Pull and Push Factors}

\begin{tabular}{|l|l|l|}
\hline Variables & Push & Pull \\
\hline Socio-cultural & $\begin{array}{l}\text { Social discrimination, family expansion, Crime, } \\
\text { religious restrictions and social Injustice }\end{array}$ & $\begin{array}{l}\text { Family reunion, family or Community } \\
\text { Commitments, education and cultural } \\
\text { Opportunities, health services }\end{array}$ \\
\hline Political & Political instability, ethnic conflict, Propaganda & Access services To public \\
\hline Economic & $\begin{array}{l}\text { Poverty, unemployment, slow economic growth } \\
\text { low wages, land tenure issues, landlessness, } \\
\text { mechanization of agriculture, depleting resources, } \\
\text { lack of infrastructure }\end{array}$ & $\begin{array}{l}\text { Employment and business } \\
\text { opportunities, higher wages, potential } \\
\text { better standard of living }\end{array}$ \\
\hline Environmental & $\begin{array}{l}\text { Environmental degradation, natural disasters, food } \\
\text { security, disease, climate change and water scarcity }\end{array}$ & $\begin{array}{l}\text { Lack of or high number } \\
\text { of people space, environmental quality }\end{array}$ \\
\hline
\end{tabular}

Source: (Riley, 20II). 


\section{Methodology}

Methodology describes the methodological approaches employed to test research hypotheses; the discussion is mainly focused on various aspects such as study design, selection criteria for respondents, study sites, sampling procedures, and sample size, construction of measuring instruments, pilot study or pre-testing and measures adopted during development of questionnaire and during field survey to collect reliable responses. The present study was planned to investigate the socio economic determinant of rural migration in urban setting in city Sargodha. Three most populous localities namely Satellite Town, Farooq Colony and Old Civil Line were selected randomly. 40 respondents in each locality were interviewed through purposive sampling technique constituting a total sample of I20 respondents. The interviewing schedule was prepared in the English but questions were asked in Urdu and Punjabi language according to the situation. The pre-testing was done on twenty male heads in order to ensure the validity and accuracy of interviewing schedule. After pre-testing and finalizing the interviewing schedule and field research activities were started for data collection.

\section{Results and Discussion}

Table I shows that a majority 62.5 percent of the respondents were males and 37.5 percent of them were females. Data regarding the age majority of the respondents 64.2 percent of them had 27-35 years of age. It shows that majority of the migrated families belong to the young age group. Data exhibited that 13.3 percent of the respondents were illiterate, while 19.2 percent of them had up to ten years school education, and a large majority 67.5 percent of them had ten year and above school education. These statics shows that majority of the respondents had better education. Data regarding income level more than one-third i.e. 38.3 percent of the respondents had less than I5000 rupees monthly family income, while I5.8 percent of them had Rs. I5000-30000 monthly family income and than one-fifth i.e. 2I.7 percent of the respondents had Above 40000 rupees monthly family income. According to the given table majority of the respondents belonged to mediocre class.

Table I: socio economic and demographic characteristics of the respondents

\begin{tabular}{|l|c|c|}
\hline Gender & Frequency & Percentage \\
\hline Male & 75 & 62.5 \\
\hline Female & 45 & 37.5 \\
\hline Age (in years) & & \\
\hline I8-2I & 5 & 4.2 \\
\hline $22-26$ & 23 & 19.2 \\
\hline $27-35$ & 77 & 64.2 \\
\hline Above 35 & 15 & 12.5 \\
\hline Education & & \\
\hline Illiterate & 16 & 13.3 \\
\hline Up to ten year school education & 23 & 19.2 \\
\hline Ten year and above & 81 & 67.5 \\
\hline Family monthly income & & \\
\hline Less than I5000 & 46 & 38.3 \\
\hline I5000-30000 & 19 & 15.8 \\
\hline 3I000-40000 & 29 & 24.2 \\
\hline Above 40000 & 26 & 21.7 \\
\hline
\end{tabular}


Table 2 shows that a large majority i.e. 70.0 percent of the respondents reported that they were migrated from rural to urban because of the availability of basic facilities i.e. job, education and good living standard were not available in villages, whereas 30.0 percent of them were replied negatively. This shows that a large majority of the respondents migrate rural to urban areas for the fulfillment of their basic needs. Data indicated that large majorities i.e. 77.5 percent of the respondents were satisfied with their present residence and 22.5 percent of them did not satisfied with their present residence in cities. Data regarding work condition of the respondents shows that little less than a half i.e. 49.2 percent of the respondents reported that they have continued the same work in urban setting, while slightly more than a half i.e. 50.8 percent of them never to have continued the same work in urban settings. Similar finding found by Farah (200I) found that the socio-economic factors age, income and education were found as the main factors shaping the migration attitude of the respondents. The majority of the respondents were young adults, not highly educated and professionals and having large-sized families. As far as their economic condition is concerned most of them fell in the low-income group. Most of them migrated for making higher income, getting better education, and achieving a better standard of life.

Table 2: Distribution of the respondents with regard to their response after migration

\begin{tabular}{|l|c|c|c|c|}
\hline \multirow{2}{*}{$\begin{array}{l}\text { Attitudinal statements } \\
\mathrm{n}=\mathrm{I} 20\end{array}$} & \multicolumn{2}{|c|}{ Yes } & \multicolumn{2}{c|}{ No } \\
\cline { 2 - 5 } & $\mathrm{F}$ & $\%$ & $\mathrm{~F}$ & $\%$ \\
\hline Migrate due to facilities were not properly available in rural areas & 84 & 70.0 & 36 & 30.0 \\
\hline Satisfaction with their residence after migration & 93 & 77.5 & 27 & 22.5 \\
\hline Have continued the same work after migration & 59 & 49.2 & 61 & 50.8 \\
\hline Thinking that confidence level increased after migration & $\mathrm{I} 02$ & 85.0 & $\mathrm{I}$ & $\mathrm{I}$ \\
\hline Financial position changed after migration & 73 & 60.8 & 47 & 39.2 \\
\hline Success to achieve the purpose/ cause of migration & 88 & 73.3 & 32 & 26.7 \\
\hline
\end{tabular}

Data demonstrates that majority of the respondents 60.8 percent were in opinion that their financial position had improved due to migrate in cities and 39.2 percent of the respondents were in the opinion that their financial condition were same as previous as rural. When the researchers asked the respondents about the accomplish the purpose or cause of migration almost one third of the respondents 73.3 percent gave the positive response regarding this statement and 26.7 percent respondents were not satisfied about their migrated design regarding their achievement in various aspects of life.

Table 23 presents the socio-economic determinants of rural to urban migration. About one-third i.e. 32.5 percent of the respondents were strongly agreed, 33.3 percent of them were agreed that they migrated rural to urban areas for their child education. 3I.7 percent of respondents were not in the opinion that they migrate for their child education. Similar result found by Farooq et al., (2005) they examined the determinants of internal migration in Faisalabad, Pakistan. 50\% of the respondents migrated due to economic reasons, $80 \%$ and $13 \%$ of the respondents were 'pushed' out of their place of origin due to poor economic and educational opportunities, respectively. Landlessness was yet another significant 'push' factor. Data show that majority of the respondents moved toward urban areas for their children's better education. Health is another important indicator a large majority of the respondents 78.4 percent agreed that due to poor health facilities they migrate and 19.2 percent respondents were not in the favor that due to health batter health facilities they migrate. A mainstream population 45.8 
percent also mentioned that they were faced transpiration problem in rural areas, to attain the better transpiration facilities they did migrate in urban settings.

Table 3: Distribution of the respondents according to their opinion about the socio-economic determinants of rural migration in urban setting.

\begin{tabular}{|c|c|c|c|c|c|c|c|c|c|c|}
\hline \multirow[t]{2}{*}{$\begin{array}{l}\text { Socio-economic determinants } \\
\mathrm{n}=\mathrm{I} 20\end{array}$} & \multicolumn{2}{|c|}{$\begin{array}{l}\text { Strongly } \\
\text { agree }\end{array}$} & \multicolumn{2}{|c|}{ Agree } & \multicolumn{2}{|c|}{ Neutral } & \multicolumn{2}{|c|}{ Disagree } & \multicolumn{2}{|c|}{$\begin{array}{l}\text { Strongly } \\
\text { disagree }\end{array}$} \\
\hline & f. & $\%$ & f. & $\%$ & f. & $\%$ & f. & $\%$ & f. & $\%$ \\
\hline $\begin{array}{l}\text { Migrate due to your children's } \\
\text { education }\end{array}$ & 39 & 32.5 & 40 & 33.3 & $\mathrm{I}$ & 0.8 & 38 & 31.7 & 2 & 1.7 \\
\hline Migrate for better health facilities & 38 & 31.7 & 56 & 46.7 & 3 & 2.5 & $2 \mathrm{I}$ & 17.5 & 2 & $\mathrm{I} .7$ \\
\hline $\begin{array}{l}\text { Migrate in city due to transports } \\
\text { problems in villages }\end{array}$ & $3 \mathrm{I}$ & 25.8 & 24 & 20.0 & 34 & 28.3 & 23 & 19.2 & 8 & 6.7 \\
\hline $\begin{array}{l}\text { Migrate rural to urban for better job } \\
\text { opportunities }\end{array}$ & 29 & 24.2 & 85 & 70.8 & 6 & 5.0 & 0 & 0.0 & 0 & 0.0 \\
\hline $\begin{array}{l}\text { Migrate because of families issues in } \\
\text { villages }\end{array}$ & 19 & I5.8 & 2 & I.7 & $\mathrm{I} 2$ & 10.0 & 50 & 41.7 & 37 & 30.8 \\
\hline $\begin{array}{l}\text { Migrate due to high rate of crimes in } \\
\text { village }\end{array}$ & II & 9.2 & 8 & 6.7 & $2 \mathrm{I}$ & 17.5 & 46 & 38.3 & 34 & 28.3 \\
\hline Feel more comfortable in city & 42 & 35.0 & 44 & 36.7 & 7 & 5.8 & 19 & I5.8 & 8 & 6.7 \\
\hline $\begin{array}{l}\text { Feel oddness in the culture of urban } \\
\text { areas }\end{array}$ & 22 & 18.3 & 32 & 26.7 & 14 & 11.7 & 40 & 33.3 & 12 & 10.0 \\
\hline $\begin{array}{l}\text { Have better relations with the } \\
\text { neighbors of urban areas }\end{array}$ & 32 & 26.7 & 52 & 43.3 & 3 & 2.5 & 30 & 25.0 & 3 & 2.5 \\
\hline Satisfied with your residence in city & 19 & 15.8 & 46 & 38.3 & 25 & 20.8 & 16 & 13.3 & I4 & II.7 \\
\hline Get fair wage in urban areas? & $4 \mathrm{I}$ & 34.2 & 46 & 38.3 & 6 & 5.0 & 22 & 18.3 & 5 & 4.2 \\
\hline $\begin{array}{l}\text { feel more esteem and confidence } \\
\text { before migration }\end{array}$ & 34 & 28.3 & 40 & 33.3 & 24 & 20.0 & 22 & 18.3 & 0 & 0.0 \\
\hline
\end{tabular}

It is noted here that a huge majority 95 percent respondents did migrate rural to urban areas for search out better job opportunities, while 5 percent of the respondents were neutral for their purpose to migrate. Similar results were also found by Sattar (2009) that educated people preferred to migrate in the cities because they migrate rural to urban areas due to the better job opportunities and secure their future. Majority of the respondents 72.5 percent were not agreed that they migrate due to the different types of families' issues in their villages. When the researcher asked to the respondents "crime rate in villages had any impact on their migrate decision". $66.6 \%$ of the respondents were not agreed with this statement. This data shows that families' issues and crime rate in villages had no major impact to the people perception to do migrate. A large majority 77.7 percent of the respondents feel pleasure and comfortable in their urban residence in lieu of rural, while 22.5 percent of the respondents were not feel combatable in urban settings. About 18.3 percent of the respondents were strongly agreed and 26.7 percent of them were agreed that they felt oddness in the culture of urban areas, II.7 percent of the respondents were neutral, 33.3 percent of them were disagreed and 10.0 percent of them strongly disagreed with this opinion. More than one-fourth i.e. 26.7 percent of the respondents were strongly agreed and a major proportion i.e. 43.3 percent of them were agreed that they have better relations with the neighbor of urban areas while 25.0 percent of them were disagreed and 2.5 percent of them strongly disagreed with this opinion. It shows that, migrants had also better relations with the neighbors of urban areas. Only I5.8 percent of the respondents were strongly agreed and 38.3 percent of them were agreed that they were satisfied with their residence in city regarding better facilities and other allied facilities, 
20.8 percent of the respondents were neutral, I3.3 percent of them were disagreed and II.7 percent of them strongly disagreed with this opinion. About one-third i.e. 34.2 percent of the respondents were strongly agreed and 38.0 percent of them were agreed that they get fair wage in urban areas of their labors, 5.0 percent of the respondents were neutral, I8.3 percent of them were disagreed and 4.2 percent of them strongly disagreed with this opinion. Data exhibited that more than one-fourth i.e. 28.3 percent of the respondents were strongly agreed and 33.3 percent of them were agreed that they felt more esteem and confidence as compare to before migration, 20.0 percent of the respondents were neutral, I8.3 percent of them were disagreed with this opinion.

\section{Conclusion}

Descriptive analysis demonstrates that insufficient, inappropriate educational, health, recreational facilities, poor infrastructure and stagnant and limited economic opportunities in rural areas were the prime factors which motivate the individuals and families to migrate to the urban areas. With increasing migration from rural to urban areas, the multi-dimensional problems such sanitation, environmental pollution, overcrowded housing, congested traffic, overpopulation, road accidents and crimes are increasing. Government should have provide better economic opportunities, better sanitation facilities, better health facilities better educational facilities, better infrastructure, better transportation, promotion of cottage industry, and establishment of small industry near the villages to divert the major flow of people from rural areas to urban areas.

\section{References}

Anonymous. 20I I. Punjab Development Statistics. Bureau of Statics Government of Punjab, Lahore.

Arif, G. M. and S. Hamid. 2009. Urbanization, City Growth and Quality of Life in Pakistan. European Journal of Social Sciences. (IO) 2.

Farah, N. 200I. Socio-economic \& cultural factors affecting migration behavior (A case study of Faisalabad [Pakistan]. Unpublished Thesis M.Sc., Rural Sociology, Univ. of Agri., Faisalabad, Pakistan.

Farooq, M., A. Mateen and M.A. Cheema. 2005. Determinants of Migration in Punjab, Pakistan: A Case Study of Faisalabad Metropolitan. J. Agri. Soc. Sci., I(3): 280-282.

Haq, A., I974. Theoretical consideration for studying socio-psychological factors in migration. The Pakistan Rev., XIII: 353-60

Henderson, V. 2002. Urbanization in Developing Countries. World Bank Research Observer, I7(I): 89-II2. Oxford University Press

Khan, I. A., S. Mahmood, G. Yasin and B. Shahbaz. 20I0. Impact of international migration on social protection of migrants families left behind in agrarian communities of district Toba Tek Signh, Punjab, Pakistan. Pak. J. Agri. Sci., Vol. 47(4), 425-428

Riley, C. 20II. Push and Pull Factors behind Migration. Retrieved Date 22/II/20I2. http://www.tutor2u.net/blog/index.php/geography/comments/study-note-push-and-pullfactors-behind-migration

Sadaf, M., I. A. Khan, A.A. Khan., B. Shahbaz and S. Akhtar. 2010. Role of international migration in agricultural development and farmers' livelihoods: a case study of an agrarian community. Pak. J. Agri. Sci. 47(3):297301 .

Sattar, H. 2009. International migration and its impact on socio-economic development in rural households in T.T. Singh. M.Sc. Unpublished thesis, Dept. of Rural Sociology, University of Agriculture, Faisalabad, Pakistan. 